\title{
ADMINISTRATIVE POLICIES AND THE COURTS
}

\section{BY JAMES M. LANDIS $†$}

The MrOST fascinating branch of American constitutional law relates to judicial review over legislative action. Here one is presented with decisions that breathe of contest between two agencies of government one, like St. George, eternally refreshing its vigor from the stream of democratic desires, the other majestically girding itself with the wisdom of the ages. Similarly, in the field of administrative law judicial review over administrative action gives a sense of battle. Courts are not unconscious of the fact that, due to their own inadequacies, areas of government formerly within their control have been handed over to administrative agencies for supervision. The legislative judgments underlying such a partitioning of government do not always convince. Thus, under the guise of constitutional and statutory interpretation, efforts to thwart the effects of those legislative judgments are not uncommon.

An approach to the problem of judicial review cannot neglect that its essence springs from the Anglo-American conception of the "supremacy of law" or "rule of law," as it is variously called. Dicey in 1885 had occasion to define its essence as follows:

"We mean," he says, speaking of the rule of law, "in the first place, that no man is punishable or can be lawfully made to suffer in body or goods except for a distinct breach of law established in the ordinary legal manner before the ordinary Courts of the land ..."1

That definition practically excludes the idea of administrative adjudication except to the extent that the administrative can report its conclusions to a court. It implies the right to a trial de novo before a judicial tribunal. However truly that may have described the area of the administrative process in 1885 , it is a misdescription of the scope of the rule of law as it exists today.

In $1936 \mathrm{Mr}$. Justice Brandeis essayed a more modern definition. "The supremacy of law," he states, "demands that there shall be opportunity to have some court decide whether an erroneous rule of law was applied; and whether the proceeding in which facts were adjudicated was con-

†Dean, Harvard Law School; Ex-Chairman, Securities Exchange Commission.

This is the fourth of a series of lectures delivered in the William L. Storrs Lecture series before the Law School of Yale University. The earlier three lectures dealt with the place of the administrative tribunal, the relationship of the administrative to the legislative, and the organization of the administrative. The series will be published by the Yale University Press in a volume entitled "The Administrative Process." This lecture is reprinted through the courtesy of the Yale University Press.

1. Dicey, Law of the Constitution (8th ed. 1923) 183. 
ducted regularly." 2 Two elements, according to this, flow from the concept of the "supremacy of law" - the right of a party to a judicial determination as to the appropriate rule of law applicable to his particular case, and the right to a judicial determination as to the regularity of the procedure employed by the administrative. Mr. Justice Brandeis' analysis of the place of the "supremacy of law" was, however, made in protest against the insistence on the part of the majority of the Court of a right to review findings of fact made by an administrative agency.

The area in which the courts insist that administrative findings of fact cannot be final is an interesting one. It seems odd, very odd, as a three-judge court has expressed it, that a Constitution "which expressly makes findings of fact by a jury of inexperienced laymen, if supported by substantial evidence, conclusive . . . prohibits Congress making findings of fact by a highly trained and especially qualified administrative agency likewise conclusive, provided they are supported by substantial evidence."s

Prior to the rise of regulatory administrative agencies, the determination of whether a particular rate charged by a common carrier was a reasonable one could be had in an ordinary judicial tribunal. The function of adjudicating upon the reasonableness of that rate was naturally, as an analytic matter, the exercise of judicial power, because it was a thing that courts did. The inadequacies of that process to deal with the rate problems of a national system of railroads led, of course, to the institution of administrative agencies. But prior to the rise of the administrative method of handling these issues, the Granger legislatures of the Middle Western States decided to deal directly with the problem of unreasonable and discriminatory rates. By statute maximum rates were established for certain roads, and in 1877 the validity of that method of handling the rate problem was upheld by the Supreme Court. ${ }^{4}$ Little was then known, however, of the proper basis of rate-making. The judicial process had developed no appropriate theories because its prior contacts with the problem had been merely through litigation involving individual rates, and the judgments setting aside particular rates did not force the courts to consider the effect of this process of supervising rates upon the operating revenues of the carrier as a whole. As ratemaking developed upon a large scale, it became clear that rate schedules could make or break a carrier as well as make or break a community or an industry. Some floor had to be created below which rates could

2. St. Joseph Stock Yards Co. v. United States, 298 U. S. 38, 84 (1936).

3. St. Joseph Stock Yards Co. v. United States, 11 F. Supp. 322, 327 (W. D. Mo. 1935).

4. Munn v. Illinois, 94 U.S. 113 (1877); Chicago, B. \& Q. Rr. v. Iowa, 94 U.S. 155 (1877) ; Peck v. Chicago \& N. W. Ry., 94 U. S. 164 (1877) ; Chicago, M. \& St. P. Rr. v. Ackley, 94 U. S. 179 (1877); Winona \& St. P. Rr. v. Blake, 94 U. S. 180 (1877). 
not be compelled to drop, and the courts set themselves to find that floor. Meanwhile, the technical difficulties of legislative rate-making became so apparent that the legislatures created administrative agencies and entrusted the task to them.

Rate-making thus, by the turn of the century, appeared to be more of a legislative power than a judicial power. The administrative was seen as taking the place of the legislature so that its functioning was easier to analogize to the exercise of power by the legislative branch of government than by the judicial branch. The fact that it acted with reference to the rate situation as a whole rather than limiting its consideration to the reasonableness of a rate as between a particular shipper and a carrier, and the fact that its orders were commands for the future and not merely judgments as to the justifiability of a past exaction, led the courts to classify its power in this respect as a legislative power. ${ }^{\circ}$ At the same time constitutional prohibitions against the strict legislative exercise of the rate-making power were in the process of development. Rates, the Court said, could not be so low as to be confiscatory. ${ }^{\circ}$ Later "confiscatory" was elaborated to be the establishment of rates so low as not to yield a reasonable return upon the value of the property devoted to the business. " But "value," in turn, had to be elaborated. Standards, which we need not examine for the moment, were set up to point to the factors upon which judgments as to "value" should rest, standards whose application left open wide areas for differences of opinion as to the weight to be attached to the various facts that related to value.

The argument for insisting upon the necessity for an independent judicial determination of findings of fact establishing values can be neatly stated in the form of a syllogism. ${ }^{8}$ Rate-making is an appropriate exercise of the legislative power provided that the rates are not confiscatory. Whether or not they are confiscatory depends upon the correctness of the finding as to value. Those facts must thus be independently found by a court in order for a court to conclude that a particular legislative act was within the legislative power; otherwise the legislature would itself be finding the facts upon which the very exercise of legislative power depends. It was thus not enough for a court to satisfy itself that the trier of the facts, the administrative, had followed the correct rules

5. Prentis v. Atlantic Coast Line Co., 211 U. S. 210, 226 (1908).

6. Reagan v. Farmers' Loan \& Trust Co., 154 U. S. 362 (1854). For earlier expressions, see Stone v. Farmers' Loan \& Trust Co., 116 U. S. 307, 331 (1836); Dow v. Biedelman, 125 U. S. 680,689 (1888); Georgia R.R. \& Banking Co. v. Smith, 128 U. S. 174; 179 (1888); Chicago, M. \& St. P. R.R. v. Minnesota, 134 U. S. 418, 455 (1890) ; Chicago \& G. T. Ry. v. Wellman, 143 U. S. 339, 344 (1892).

7. Smyth v. Ames, 169 U. S. 466 (1898).

8. See Buchanan, The Ohio Valley Water Company Case and the Valuation of Railroads, (1927) 40 Harv. L. Rev. 1033, 1037; Comment (1936) 50 Hasv. I. Rev. 78, 83. 
as to valuation. Instead, the actual determination of value had to be made by the court.

It was this reasoning that led the Supreme Court of the United States in 1920, in the Ohio Valley Water case, ${ }^{\theta}$ to hold unconstitutional a Pennsylvania statute which the Pennsylvania courts had concluded limited the right of judicial review over administrative determination of value, to inquiry simply as to whether there was evidence to support the administrative finding. More was needed by the Constitution in order for the Court to be sure that the purported exercise of legislative power was really an exercise of such power, and this was an independent judicial determination upon the facts relating to value. Similarly, in 1936, the Court in the St. Joseph Stock Yards case, ${ }^{10}$ though it upheld an order of the Secretary of Agriculture fixing the maximum rates that could be charged by a stockyards company, insisted that the Constitution required a court not merely to find that the Secretary had evidence upon which to reach his findings as to the value of the property, but to find of its own accord that upon the same evidence the Court would reach the same conclusion as to the value of the property. ${ }^{11}$

This does not mean that in any proceeding in which valuation is in issue an administrative finding does not have the same finality as a jury verdict. Law refuses to be that simple. In tax cases or in condemnation cases when the amount due from, or payable to, a party depends upon the valuation of property, 'an administrative finding on valuation is final if supported by evidence. No independent judicial determination of value is required. ${ }^{12}$ "True, the same type of syllogistic reasoning might be advanced in cases of this character. For the constitutionality of the

9. Ohio Valley Water Co. v. Ben Avon Borough, 253 U. S. 287 (1920).

10. See note 2 , supra.

11. The distinction between mere review over administrative determination and insistence upon independent judicial determination of the facts has been aptly summarized by the court in St. Joseph Stock Yards Co. v. United States, 11 F. Supp. 322, 327 (1935) as follows: "When it is said that an independent judgment must be reached by the court, it is meant that the court's findings must be determined by the weight of the evidence and not by a consideration as to whether the findings of the administrative agency are supported by substantial evidence or are arbitrary. A finding may well be supported by substantial evidence and still be against the weight of the evidence. The advocates of each of the two theories, (1) that the Court must give its independent judgment on the record made and that, (2) it must accord a de novo hearing, agree that the findings of the administrative agency should be looked upon as presumptively correct. That is far less, however, than an acceptance of the findings of the administrative agency as conclusive if they are supported by substantial evidence or are not arbitrary."

12. Bauman v. Ross, 167 U. S. 548 (1897); Long Island Water Supply Ca. v. Brooklyn, 166 U. S. 685 (1897); Crane v. Hahlo, 258 U. S. 142 (1922); San Diego Land \& Town Co. v. Jasper, 189 U. S. 439 (1903); Kentucky Rr. Tax Cases, 115 U. S. 321 (1885). 
exaction of any particular sum depends upon whether the appropriate ratio exists between the charge and the valuation of the property. Error in valuation would mean an unconstitutional exaction, so that to prevent an unconstitutional exercise of power an independent judicial determination as to value should be had. Proceedings in tax and condemnation cases, however, are so like ordinary judicial proceedings that the readier analogy for the Court in these cases is to liken administrative adjudication to judicial adjudication. In the latter findings of fact by juries are conclusive if supported by evidence; so by analogy findings of administrative tribunals were given the same degree of finality.

A similar problem arose shortly after the enactment of the Longshoremen's and 'Harbor Workers' Compensation Act. ${ }^{13}$ The story of the effort to extend the benefits of workmen's compensation to persons engaged in maritime employment is a grim comedy of errors. After two futile attempts to bring these persons within the operation of state workmen's compensation legislation, ${ }^{14}$ the Congress in 1927 set up a system, modelled upon the state workmen's compensation laws, to govern workers within the admiralty jurisdiction of the United States. The constitutional power of the Congress in this respect extends only to the admiralty jurisdiction. Whether or not a particular employee at a particular time is within that jurisdiction involves not only hyper-technical questions of law but depends also upon what the facts with reference to his employment and the situs of the injury are found to be. ${ }^{10}$ Furthermore, his right. to compensation rests, among other things, upon his ability to establish the existence of an employer-employee relationship at the time of the injury. In 1932 in Crowell v. Benson ${ }^{10}$ the Court held that administrative findings of fact on these two issues could. not be made final, in the sense that they should stand if there was substantial evidence to support them. Instead, these two facts being jurisdictional in the sense that the constitutional power of the Congress could extend only to certain states of fact, an independent judicial determination had to be had with reference to them. The syllogism here is again apparent. Constitutional power, according to the Court, extended only to the admiralty jurisdiction and only to the imposition of absolute liability where the employer-employee relationship existed. Constitutional power to deal with the relationships involved in any particular case, therefore, depended upon the existence of certain facts, and unless those facts were found by

13. Act of March 4, 1927, c. 509, 44 Stat. 1424.

14. Southern Pacific Co. v. Jensen, 244 U. S. 205 (1917); Knickerboclier Ice Co. v. Stewart, 253 U. S. 149 (1920); Washington v. Dawson \& Co., 264 U. S. 219 (1924). See Palfrey, The Common Law Courts and the Law of the Sca, (1923) 36 Harv. L. REv. 777; Comment (1924) 37 HaRv. L. Rev. 478.

15. Comment (1927) 40 Harv. L. Rev. 485.

16. 285 U. S. 22 (1932). 
a court no assurance could be had that the particular case lay within the sphere of the federal admiralty jurisdiction. The argument of the minority that such syllogistic reasoning had equal application to other facts upon which the issue of liability depended, was ignored by the majority, as well as the plea that a sensible administration of justice demanded that a degree of finality should attach to administrative findings of fact.

I shall give a further illustration of the incidence of this doctrine relating to so-called jurisdictional or constitutional facts as it concerns another field. The power of the administrative to exclude or deport an alien depends upon whether a particular individual is in fact an alien. Indeed, the constitutional limits of the power to exclude or deport depend upon that issue of alienage. An administrative finding of fact that an individual is not a citizen but an alien is final when the issue is one of exclusion. ${ }^{17}$ But when the issue is one of deportation, such finality ceases to attach to that administrative finding. Instead, the party threatened with deportation is entitled to an independent judicial determination of his claim that he is a citizen of the United States. ${ }^{18}$

On the basis of logic the series of cases relating to jurisdictional and constitutional facts is irreconcilable with those that grant finality to administrative determinations of fact. They seem equally indefensible from the standpoint of practical judgments as to the appropriate area of administrative activity. It is true that in the deportation and exclusion cases two great differences of a practical nature are to be found. The first is that the process of exclusion, because of the number of aliens seeking entry, demands something akin to a summary procedure, whereas deportation exerts no such pressure either in numbers or in the necessity for speed of disposition. ${ }^{18}$ The second is that the penalty of deportation normally has more serious consequences. It tears up and disrupts the pursuit of a livelihood that has already been entered upon; exclusion simply denies the right to find new surroundings for living.

But if we move from these cases to the others, practical judgments as to the desirability of court intervention fail to tally with the legalistic conclusions. In the field of rate-making the effect of the Ohio Valley Water case, coupled with the insistence of the Court that reproduction cost must be given fair consideration in the determination of valuc, has been to prolong interminably the process of administrative rate-making. A delay of ten or fifteen years, an expenditure of millions of dollars, constant interruption of administrative proceedings by appeals to the courts, have brought the regulatory process into contempt. The practice of appealing to the Court on every issue of fact relating to valuation has

17. United States v. Ju Toy, 198 U. S. 253 (1905).

18. Ng Fung Ho v. White, 259 U. S. 276 (1922).

19. See Van Vleck, The Administrative Control of Aliens (1932) 210. 
transformed what should be a business-like proceeding into a bitter, wrangling lawyers' battle. That after these many years of the effort to develop workable regulatory controls, the New York State Commission on the Revision of the Public Service Commissions Law can report that "effective regulation along the lines originally intended by the Act has broken down," 20 spells little in the way of credit to the judicial moulding of the area of administrative rate regulation.

In the field of workmen's compensation judicial review of administrative findings of jurisdictional fact has equally little to commend it. If Crowell $v$. Benson is to require the reintroduction into the administration of workmen's compensation legislation of the necessity for independent judicial determination of those facts upon which the jurisdiction of the administrative rests - to say nothing of its intimation that a trial de novo upon these issues is required - the very efficiency of the system becomes threatened. Judicial review upon the issue of interstate commerce, as that issue is raised by litigation under the Federal Employers' Liability Act, had little to commend it. After twenty-five years of incessant litigation the boundaries of that Act were still undefined. Yet, in those twenty-five years, it was before the Supreme Court 172 times. $^{21}$ A judgment upon such a problem as is involved in questions such as that Act raised, or upon issues of fact such as those presented by Crowell v. Benson, as distinguished from a judgment establishing a rule of conduct, has neither force as a precedent nor as a decision is it capable of analogical development. It settles that case alone, and opening up such determinations to appellate review makes against the finality that should attach to litigation, particularly in these fields. One especially unfortunate effect attaching to judicial intervention in cases of this character has been aptly summarized by Mr. Justice Brandeis in his comment upon the practical effect of Crowell a'. Benson upon the administration of the Longshoremen's and Harbor Workers' Act. "Since." he says, "the advantage of prolonged litigation lies with the party able to bear heavy expenses, the purpose of the Act will in part be defeated." 2 -

The explanation of these insistences that the administrative process in these phases must be subject to judicial review firids, I helieve, some answer in economic determinism. But the deeper answer lies in our traditional notions of "law" as being rules administered and developed by courts. We must remember that until a comparatively short time ago Anglo-American government was essentially government by judges. The great mass of our law was developed by the resolution of conflicting

20. N. Y. State Comasission on Revisiox of the Puglic Semuce Cossussions LAw, REPORT OF COMraisstoners (1930) 1.

21. Schoene and Watson, Workmen's Compensation on Interstalc Railuays (1934)

47 HARv. L. REv. 389.

22. Crowell v. Benson, 285 U. S. 22, 94 (1932). 
claims in courts where the governing rules were evolved by the judge. In contract, in tort, in negotiable instruments, in trusts - the body of our law is judge-made and represents the successive reactions to practical situations of a professional class that was nurtured in the same traditions and was subject to the limitations of the same discipline. ${ }^{23}$ That class has had pride in its handiwork. Nor can one deny its right to pride. But the claim to pride tends, especially in the hands of lesser men, to be a boast of perfection. It is a rare greatness that recognizes experience as the life of the law. A lesser vision, fearful of the frailty of human thought and human judgment, claims Delphic powers, and rests the learning of the law upon an affinity with deep and mysterious principles of justice that none but itself can grasp. Deep resentment thus attaches to any criticism of its inadequacies, any suggestion as to its biases. To admit to the dispensation of justice other individuals, no matter how wise, who are not bound by the older disciplines, is regarded with horror.

Chief Justice Hughes, in addressing the Federal Bar Association in 1931, speaks of the growth of administrative law in the following fashion:

"A host of controversies as to provisional rights are no longer decided in courts. Administrative authority, within a constantly widening sphere of action, and subject only to the limitations of certain broad principles, establishes particular rules, finds the facts, and decides as to particular rights. The power of administrative bodies to make findings of fact which may be treated as conclusive, if there is evidence both ways, is a power of enormous consequence. An unscrupulous administrator might be tempted to say, 'Let me find the facts for the people of my country, and I care little who lays down the general principles.' We all recognize that this development has been to a great extent a necessary one . . . Experience, expertness and continuity of supervision, which could only be had by administrative agencies in a particular field, have come to be imperatively needed. But these new methods put us to new tests, and the serious question of the future is whether we have enough of the old spirit which gave us our institutions to save them from being overwhelmed." 24

But it is just because some of those old institutions had proved inept for a modern society that a new spirit has sought to shift their emphasis.

I spoke before of the issue of judicial review over administrative action giving one the sense of battle. Nowhere does that more clearly come to the surface than in the recent case of Jones w. Securities and Exchange Commission. ${ }^{25}$ In the early days of the administration of the Securities

23. Landis, Business Policy and the Courts (1938) 27 YALE REv. 235.

24. New York Times, February 13, 1931, p. 18.

25. 298 U. S. 1 (1936). 
Act of 1933 the question was raised of how to handle a registrant's request to be permitted to withdraw his registration statement prior to its effectiveness. Examination of a registration statement filed with the Commission might give rise to a belief that some of the assertions it contained were false. A quiet investigation into the facts would then be made, and, if this gave ground for that belief, stop order proceedings would then be initiated. To avoid public exposure of an attempt to defraud the public, a registrant might seek to withdraw. The withdrawal of the statement would, it is true, operate to prevent the acquisition of any right to offer to the public the securities that were sought to be registered. As such it had an effect similar to the entry of a stop order. But misstatement of material facts and the avowed attempt to defraud the public seemed to the Commission serious matters. To allow a registrant to escape the consequences that should flow from such misconduct by the simple act of withdrawing his registration statement appeared inadequate. It was possible, as a theoretical matter, to try to indict a registrant whose misstatements had been deliberate; but the chances of conviction for crime, when, due to the vigilance of the administrative no one had been defrauded, are doubtful. ${ }^{26}$ The better course seemed to be to establish a record of fraud after a hearing and in such a manner inform the investment world of the fraud that was attempted and the character of parties to it. With that in mind, a rule was adopted making withdrawal depend upon the consent of the Commission, and a practice was pursued of denying withdrawals whenever there was reasonable ground to believe that deliberate, material misstatements had been made by a registrant.

In 1936 the validity of that practice was challenged in the Supreme Court of the United States. Doubt quite generally existed as to the power of the Commission to promulgate a rule governing withdrawals in view of the silence of the statute upon the subject of withdrawals; but assuming the validity of the rule, the exercise of discretion to deny withdrawals in the manner indicated scemed quite appropriate. The Supreme Court, however, took a different view. It assumed that the general rule was valid but denied any power to the Commission to refuse withdrawals in cases where the registration statement was still ineffective and where no securities had as yet been sold.

Such a result was not too surprising. But the process of thought by which the Court reached its conclusion still startles. By analogical reasoning of a familiar character, the Court likened the stop order proceeding to a suit in equity. Then finding that the equity practice permitted a plaintiff to withdraw his suit at any time, if that withdrawal would not

26. Two parties involved in the stock promotion, the facts of which are set forth in In the Matter of Continental Distillers and Importers Corporation [1 S. E. C. 54 (1935)] were indicted in the Supreme Court of the District of Columbia but were acquitted. 
prejudice the defendant, it concluded that this equity practice must bind the Commission. Consequently the Commission should not have denied the request of the particular registrant to withdraw his statement. Had the Court stopped there, one might have regretted its conclusion as weighting the scales in favor of fraudulent promoters, but that would have been all. Had the case involved a misapplication of the equity practice by any inferior judge, the Court would have stopped there, pointed out the error, and reversed his conclusion. But for the Commission not to realize that its stop order proceedings were like suits in equity and not to be aware of the equity practice was not merely to commit an error; in the words of Mr. Justice Sutherland, it was "the assumption of arbitrary power by an administrative body." ${ }^{27}$ "The action of the Commission," Mr. Justice Sutherland thundered, "finds no support in right principle or in law. It is wholly unreasonable and arbitrary. It violates the cardinal precept upon which the constitutional safeguards of personal liberty ultimately rest-that this shall be a government of laws - because to the precise extent that the mere will of an official or an official body is permitted to take the place of allowable official discretion or to supplant the standing law as a rule of human conduct, the government ceases to be one of laws and becomes an autocracy." 28 There was more in this vein - suggestions of unreasonable search and seizure, and intimation that the Commission's action was "among those intolerable abuses of the Star Chamber, which brought that institution to an end at the hands of the Long Parliament in 1640"20 - a remark that brought forth from Mr. Justice Cardozo the terse comment: "Historians may find hyperbole in the sanguinary simile." 30

Such an outburst indicates that one is in a field where calm judicial temper has fled. Deep feelings underlie this unguarded language of $\mathrm{Mr}$. Justice Sutherland. They underlie, too, the suggestion by the Chief Justice that the administrative is prone to abuse the powers entrusted it. Rhetoric of this nature has a purpose. If it is fair to apply the legal rule that one intends the natural and probable consequences of his acts, certainly the effect if not the purpose was to breed distrust of the administrative. Invective, such as $\mathrm{Mr}$. Justice Sutherland hurled at the Commission for an action that three Justices commended as "wisely conceived and lawfully adopted to foil the plans of knaves intent upon obscuring or suppressing the knowledge of their knavery" 31 - an action which, at its worst, was a pardonable technical error - was naturally seized upon by every opponent of security regulation, for none of them, even in the

27. Jones v. Securities and Exchange Commission, 298 U. S. 1, 19 (1936).

28. Id., at 23-24.

29. Id., at 28 .

30. Id., at 33 .

31. Ibid. 
heat of the legislative struggle, had indulged in such hyperbole. Its effect was not to promote that calmness of atmosphere in which wise administration flourishes. For months thereafter every effort to deal with fraudulent promoters was met by the accusation that Star Chamber tactics were being employed. But worse, to the uninitiated who have neither time nor the ability to grasp the precise issue involved by a particular case, the cause of good administration suffered by this excoriation, naturally headlined by the press, of administrative action as arbitrary and violative of ancient rights and privileges.

The most disputed field of judicial review over administrative action today concerns the finality of administrative findings upon so-called issues of constitutional or jurisdictional fact. Apart from the incidence of that problem in the immigration field, the cases, upholding the claim to an independent judicial determination of these issues, have all been decided by a divided Court. In the Ohio Valley Irater case, three Justices dissented; in Crowell a'. Benson, three Justices dissented; in the St. Joseph Stock Yards case, three Justices dissented from the conclusion of the Court on this point, and a fourth Justice, MIr. Justice Roberts, indicated by his memorandum of concurrence and his earlier dissent in Crowell v. Benson, doubt as to the validity of the Court's position; in Baltimore \& Ohio R.R. '1. United States, ${ }^{32}$ a case in which the majority took occasion by way of dictum to reiterate its views, four Justices took occasion to emphasize that they would not support the majority on that issue. In view of these divisions, the law as to what finality shall attach to administrative findings of fact is likely to reflect the minority's rather than the majority's view. Because their reasoning seems more to accord with the temper of the times, it is they, rather than the majority, who are likely to gain adherents to their position.

The basis of the minority's position is thus of absorbing interest. Its rejection of the syllogistic position of the majority is unimportant. What matters are the positive reasons advanced for its conclusions. They group themselves about the thesis that the more appropriate tribunal for the determination of these issues is the administrative. Great emphasis, however, is placed upon the constitution of the adjudicating administrative agency. Its composition and its procedure condition its fitness as an instrument for the determination of these issues. Mr. Justice Brandeis twice notes that in these cases the Court is not dealing with informal, summary administrative action based on ex parte-casual inspection or unverified information, where "no record is preserved of the evidence on which the official acted," but "with formal, deliberate quasi-judicial decisions of administrative tribunals, based on findings of fact expressed in writing, and made after hearing evidence and argument under the

32. 298 U. S. 349 (1936). 
sanctions and the safeguards attending judicial proceedings." 33 The choice by the legislature of such a procedure for the determination of these issues of fact is thus not deemed by him to involve a violation of the due process clause.

The minority is not only sympathetic with the administrative process; it hopes to encourage its capacity to dispose more effectively of the business entrusted to it. It fears that the majority doctrine, by reserving judgment on these issues to the courts, will imperil the responsibility that should attend the administrative process. Indeed, a world of difference in temper and in outlook separates the denunciatory fervor of $\mathrm{Mr}$. Justice Sutherland in the Jones case from the hope of the administrative process that inheres in Mr. Justice Brandeis' observation-- "Responsibility is the great developer of men." 34

The positive reason for declining judicial review over administrative findings of fact is the belief that the expertness of the administrative, if guarded by adequate procedures, can be trusted to determine these issues as capably as judges. If so, it is only delay that results from insistence upon independent judicial examination of the administrative's conclusion. This evaluation of the scope of judicial considerations in terms of administrative expertness points to the reasons for the differentiation of treatment between the rate-making cases and the inmigration cases. The minority has explained that distinction upon two bases. One is that the adjudications are not made by quasi-judicial administrative agencies that transact their business in a manner similar to courts. This premise, however, is questionable in view of the internal organization of the office of the Commissioner of Immigration. The other basis is that the right involved is more than a property right; it is the right to the liberty of the person. It is true that the claim "Civis romanus sum" echoes down the ages with more power to stir the heart than a claim that property has been undervalued. One cannot criticize a magistrate who feels an urge to give it every protection that he can. But apart from these bases for distinction, it should be observed that the issue of citizenship is triable in a simple manner. Little in the way of expertness is demanded for its determination. The record of facts that underlies its establishment is a simple one. In their most extended form such records do not reach the 3466 pages that the Court had hefore it in the St. Joseph Stock Yards case. That, after all, was "ratc regulation in its simplest form," as contrasted with the 36,893 pages, not including 3,324 exhibits, that comprised the record before the District Court in the New York Telephone Company rate case. ${ }^{35}$

33. St. Joseph Stock Yards Co. v. United States, 298 U. S. 38, 81 (1936); see also Crowell v. Benson, 285 U. S. 22, 88 (1932).

34. St. Joseph Stock Yards Co. v. United States, 298 U. S. 38, 92 (1936).

35. Id., at 90 . 
If the extent of judicial review is being shaped, as I believe, by reference to an appreciation of the qualities of expertness for decision that the administrative may possess, important consequences follow. The constitution of the administrative and the procedure employed by it become of great importance. That these factors already in part mould the scope of judicial review is apparent from the decisions. Different agencies receive different treatment from the courts. A reputation for fairness and thoroughness that attaches to a particular agency seeps through to the judges and affects them in their treatment of its decisions. Fairness and thoroughness may also be apparent upon the record as it reaches the court, so as to lead the court to the conclusion that the evidence has received the attention that it deserved and that it would have received in the hands of one trained in legal techniques.

The interesting problem as to the future of judicial review over administrative action is the extent to which judges will withdraw, not from reviewing findings of fact, but conclusions upon law. If the withdrawal is due to the belief that these issues of fact are best handled by experts, a similar impulse to withdraw should become manifest in the field of law. This problem can be seen better, I think, if put concretely. An administrative finding in a rate-making controversy as to the value of a particular generating station, made after hearing and upon evidence, we may assume will hereafter be final. The administrative, whose daily concern is the consideration of these matters, is recognized to possess greater competence in appreciating the learing and weight of testimony upon that issue than would characterize either a judge or a jury. For this reason to allow finality to rest with the administrative violates no constitutional prohibition. But the same considerations of expertness have validity in the field of law. A determination by an administrative agency that a particular trade practice is an unfair method of competition is a determination theoretically not of fact but of law. But despite the assumed expertness of the administrative in weighing the economic consequences attendant upon that practice, its decision as yet has no finality. The scope of judicial review in such a case is wholly different.

I use these terms "fact" and "law" knowing how tenuous the distinction between them is. Professor Dickinson in his study on Aluministrative Justice and the Supremacy of Law in the Linited States rejects the distinction completely. "In truth," he says, "the distinction between 'questions of law' and 'questions of fact' really gives little help in determining how far the courts will review; and for the good reason that there is no fixed distinction. They are not two mutually exclusire kinds of questions, based upon a difference of subject-matter. Matters of law grow downward into roots of fact, and matters of fact reach upward, without a break, into matters of law . . . It would seem that when the courts are unwilling to review, they are tempted to explain by the 
easy device of calling the question one of 'fact', and when otherwise disposed, they say that it is a question of 'law'." 36

It is impossible to disagree with this statement as a description of the present state of the decisions dealing with judicial review of adminis trative action. But the rejection of the distinction, though it may accord with the fact, leaves nothing upon which to base a philosophy as to the appropriate spheres of administrative and judicial activity. If our basic constitutional conceptions adhere to a belief in the "supremacy of law" - a belief in an inviolable area for the resolution of claims by courts - it must give some content to the word "law." Collecting the cases and illustrating how the scope of judicial review varies with reference to different administrative agencies and different areas of activity will give a picture of its operation. But such an analysis fails to satisfy the demands for a creative philosophy that seeks a basis upon which to allot law-making by adjudication as between courts and administrative.

Section.10(a) of the Securities Exchange Act authorized the Commission in connection with the purchase or sale of any securities to proscribe the use of "any manipulative or decentive device or contrivance" by rule or regulation, as the Commission might deem necessary or appropriate in the public interest or for the protection of investors. By the amendments of 1936 brokers and dealers in the over-the-counter market were forbidden to effect transactions in securities by means of "any manipulative, deceptive, or other fraudulent device or contrivance," and the Commission was empowered by rule or regulation to "define such devices or contrivances as are manipulative, deceptive or otherwise fraudulent." Pursuant to the authority granted by these sections the Commission adopted a series of rules forbidding certain specified practices that it conceived to be "manipulative, deceptive or fratudulent." Among them is the requirement that a broker or dealer who controls, or is controlled by the issuer of a security must disclose the existence of that control before entering into any contract with a customer for the purchase or sale of thai security. Another rule forbids a broker or dealer who handles a discretionary account to make purchases or sales in that account which are excessive in size or frequency, in view of the financial resources and character of that account. A third forbids a distributing broker or dealer to offer securities "at the market" unless he believes that a market exists for that security other than such as he or his associates may create.

Here are samples of law-making by regulation, specifically pricking out the content of the statutory concept of "manipulative, deceptive and fraudulent" devices. The authority of the Commission to promulgate and enforce these rules can, of course, be tested in court. Such a suit

36. Dickinson, Administrative Justice and the Suprenacy of Law in the UNITED STATES (1927) 55. 
would raise the issue of whether the action taken was within the authority granted to the Commission. That issue would lead the court generally to consider whether the particular conduct described in any particular rule could fairly be called "manipulative, deceptive or fraudulent." But the court would hardly ask itself whether it would, of its own accord, have prescribed such a rule. In other words, the scope of judicial review in such a case would be somewhat akin to that of judicial review over the validity of legislation challenged under the due process clause. A reasonable belief held by the administrative, since it was acting in the manner of a legislature, that such practices tended to promote fraud and deceit in the security markets would, in all probability, be sufficient upon which to base the validity of the rule. The administrative judgment upon this issue would tend further to have much weight because of its assumed expertness.

It is true that in two recent cases the Supreme Court of the United States indulged in talk to the effect that the promulgation of such regulations in order to have validity must be buttressed by findings of fact. ${ }^{37}$ How far this suggestion should be taken seriously is a matter of considerable doubt. Rules of this character are themselves evidence of administrative judgment that the particular conduct embraced by them does normally promote fraud and deceit. A further recital to that effect would be a matter of mere formality. The evidence upon which the conclusions that lead to the adoption of such rules rests is rarely of a type that is legally admissible for the patent reason that it was not gathered for the purpose of introducing it in an adversary proceeding. It resembles more the type of evidence adduced in a hearing before a Congressional committee. In the main it consists of opinions of men acquainted with the practices of the security markets. Instances may have come to the attention of the administrative of actual losses caused by those practices which thus focussed the Commission's attention upon the desirability of putting an end to conduct of that type. But the ultimate judgment of the administrative rests on considerations that evolved out of a wide range of experience and observation and out of its study of security practices. To set them forth in detail would make a treatise on practices in the over-the-counter market rather than a limited series of recitals. To require this range of evidence to be reduced to findings of fact is as equally unrealistic as to impose a requirement upon legislatures that specific findings of fact must be a prelude to the passage of legislation. $^{38}$ These suggestions of the Court that findings of fact are

37. Panama Refining Co. v. Ryan, 293 U. S. 388 (1935); Schechter Poultry Corp. v. United States, 295 U. S. 495 (1935).

38. But see Oppenheimer, The Supreme Courl and Administralize Lan', (1937) 37 CoL. I. REv. 1, 15. I have had occasion elsewhere to comment upon the desirability of recitals, but to lift them to the level of jurisdictional requirements seems unrealistic. 
a condition precedent to administrative rule-making have yet to be elaborated before their meaning can be understood.

The incidence of judicial review over administrative law-making by way of rules can be contrasted with the scope of judicial review in cases where the law-making of the administrative flows from adjudication. Under Section 5 of the Federal Trade Commission Act the administrative is authorized to restrain "unfair methods of competition" in interstate commerce. No express power to define unfair competition by regulation was granted to the Commission. Instead, the pricking out of such rules as alone can make real the nature of "unfair methods of competition" came from the process of adjudication. Judicial review over these decisions takes on a different character. The Court now avowedly inquires into the wisdom of any particular rule that the administrative may have evolved and considers its likeness to existing doctrine in the field. In the first case under this Section that reached the Supreme Court, Federal Trade Commission v. Gratz, ${ }^{39}$ the Commission had ruled that the refusal of a jobber, who held a dominant and controlling position in the sale of cotton ties, to sell ties unless the purchaser would agree to buy a proportionate share of cotton bagging was an unfair method of competition. The Supreme Court reversed the Commission over the dissent of two Justices. In considering the question of whether to uphold the action of the administrative the Court did not limit itself to the consideration of whether reasonable grounds existed for the Commission's conclusion. Such grounds clearly did exist. The Court instead conceived its function to embrace the right independently to determine what the appropriate rule of law should be. Its approach was identical with that which it would possess were it reviewing a legal ruling by a lower court. This remains the general doctrine. It is true that on occasion some deference will be paid to the administrative judgment on the ground that it possesses some expertness with reference to the subject-matter, but the deference is a matter of attitude in a particular case rather than of doctrine.

The conception that judicial review of administrative adjudication and of administrative legislation should be assimilated to each other has yet to gain recognition. But the problem seems essentially to have the same core. For the issues raised by the effort to find the apnropriate governing rule through adjudication require appreciation and evaluation of a wide variety of business facts. In that process there is room for differences of opinion, differences that spring from the degree of emphasis placed upon these facts. The expert judgment of the admin-

See Landis, The Study of Legislation In Law Schools (1931) 39 Harv. Grad. MaG. $433,441$.

39. 253 U. S. 421 (1920). 
istrative here, however, counts for little, for since the rule evolves as a result of the process of adjudication it now partakes of the nature of a question of law, and upon that issue an ultimate and independent judgment is said to rest with the court.

It would have added much to our ideas of the appropriate spheres for judicial and administrative activity, if the administrative in a field such as this had been given the power to evolve the meaning of "unfair methods of competition" by regulation as well as by decision. The relationship of judicial review to forms of administrative activity dealing with the same subject-matter might thus have been more sharply brought into focus. As it appears now, we seem to have one of those curious paradoxes of the law. In Truax $v$. Corrigan ${ }^{40}$ the Supreme Court held that the State of Arizona by legislation could not bring about a rule of law which even then had been established by judicial decision in the State of New York as the governing rule of human conduct.11 In the field of administrative activity it may be that results can be reached by the process of administrative legislation which cannot be achieved through administrative adjudication.

I return thus to the issue of "law" as being the dividing line of judicial review - as bounding the province of that "supremacy of law" that is still our boast. Its content, insofar as it relates to judicial review of administrative action, seems to me to reach back to the issue of expertness. Our desire to have courts determine questions of law is related to a belief in their possession of expertuess with regard to stch questions. It is from that zery desire that the nature of questions of law emerges. For, in the last analysis, they secm to me to be those questions that lawyers are equipped to decide.

To view "law" in this fashion seems to me to bring reason into our conceptions of the supremacy of law. It seems to afford some guide to moulding the process of judicial review over both legislative and admin-

40. 257 U. S. 312 (1921).

41. This is the contention advanced by Mrr. Justice Brandeis in his dissenting opinion. He points to the fact that in his judgment the Arizona statute, held unconstitutional by the majority, set forth the substance of the common law as it had been declared by the courts of Ohio, Minnesota, Montana, New York, Olikhoma and New Hampshire. I should question, however, whether the common law of any of these states legalized the particular type of picketing involved in the Truax Case, which the Supreme Court of Arizona, because of the statute, held was not subject to the injunctive processes of the state courts. Similar paradoxes are to be found. Compare. for example, the restrictions upon state legislative action in violation of the due precess clause and the scope of such restrictions as applied to state judicial action. Comment (1923) 36 Harv. L. Rev. 1022; Comment (1923) 37 HARv. L. Rev. 247. Sce also the effort to extend the impairment of the obligation of contracts clause to protect against judicial as well as legislative action in Muhlker v. New York \& Harlem Rr., 197 U. S. 544 (1905). 
istrative action. It explains the variances in the scope of judicial review over administrative agencies of different compositions and charged with the disposition of different subject-matters. It lends emphasis to the insistence of $\mathrm{Mr}$. Justice Brandeis that differences in treatment should be accorded to findings of fact by different administrative officials, because of differences in the facts and in the qualities of the administrative to be expert in finding the facts. It removes nothing from the insistence that policy plays a commanding role in the shaping of judicial review, but in the place of a simple theory of economic determinism, or of a barren logic, it substitutes a sense of emphasis upon intellectual quality and discipline as related to a particular problem. The line of demarcation will then speak in terms of reality, in terms of an appreciation of the limitations and abilities of men, rather than in terms of political dogma or of righteous abstractions.

Of course, such a conception of law as related to spheres of judicial and administrative activity affords no definite answers. It must not do so, for the capacities of men and the nature of disciplines will vary. But it does point to the elements that should control judgment. And from the standpoint of affording conceptions of liberty real meaning, one can ask little more than to have issues decided by those best equipped for the task.

Such a conception of the nature of law does not remove the sense of battle which dominates the question of judicial review over administrative action. But it makes that contest rest upon a plane where the issues relate to the ability of men to handle subject-matter. As such, the contest should partake more of that rivalry that attends the academic scene, where a passionate desire for truth makes for recognition and not resentment of achievement.

The world of today as distinguished from that of even a hundred years ago is one of many professions. We can no longer divide it, in its civil aspect, between the church, the law, and medicine. Economics, politic science, sociology, social ethics, labor economics, engineering in its various branches, all are producers of disciplines relating to the arrangement of human affairs. Government today no longer dares to rely for its administration upon the casual office-seeker. Into its service it now seeks to bring men of professional attainment in various fields and to make that service such that they will envisage the art of governance as a career. The desires of these men to share in the mediation of human claims cannot be denied; their contributions dare not casually be tossed aside.

The grandeur that is law loses nothing from such a prospect. Instead, under its banner as a commanding discipline are enlisted armies of men dedicated to the idea of justice. But to use those armies, a sense of the 
effectiveness of their units is essential and an instillation in those units of morale. "Courts," as Mr. Justice Stone has reminded us, "are not the only agency of government that must be assumed to have capacity to govern;" 42 nor are they, one can add, the only agency moved by the desire for justice. The power of judicial review under our traditions of government lies with the courts because of a deep belief that the heritage they hold makes them experts in the synthesis of design. Such difficulties as have arisen have come because courts cast aside that role to assume to themselves expertness in matters of industrial health, utility engineering, railroad management, even bread-baking. ${ }^{43}$ The rise of the administrative process represented the hope that policies to shape such fields could most adequately be developed by men bred to the facts. That hope is still dominant, but its possession bears no threat to our ideal of the "supremacy of law." Instead, it lifts it to new heights where the great judge, like a conductor of a many-tongued symphony, from what would otherwise be discord, makes known through the voice of these many instruments the vision that has been given him of man's destiny upon this earth.

42. United States v. Butler, 297 U. S. 1, 87 (1936).

43. See Landis, Address before the Fourth Annual Woman Congress, March 10, 1937, 81 CoNG. REc. App. 503. 